\title{
Spatial Dependency of Buruli Ulcer on Land Surface Temperatures and Elevations in some Endemic and Non-Endemic Districts of Ghana
}

\author{
Saviour Mantey ${ }^{1}$, Naa Dedei Tagoe ${ }^{1}$ \\ ${ }^{1}$ Department of Geomatic Engineering, University of Mines and Technology, Tarkwa, Ghana
}

\begin{abstract}
This research examined the effect of Land Surface Temperatures (LSTs) and elevations by the synthesis of remote sensing and landscape metrics on the spread of Buruli Ulcer $(B U)$ caused by Mycobacterium Ulcerans (MU) in the Amansie West District (AWD), Upper Denkyira West District (UDWD), with Tarkwa Nsuaem Municipal (TNM) as a case control study area. LST maps were derived from Landsat Thematic Mapper (TM), Landsat Enhanced Thematic Mapper plus (ETM+) and Landsat Operational Land Imager (OLI). In-situ ground truth temperatures were used together with the derived LSTs from the Landsat data. Elevation maps were also generated from ASTER Global Digital Elevation Models (GDEM) and from fieldwork. Epidemiological data of disease were collected from the National Buruli Ulcer Control Programme, District Hospitals and from fieldwork. Twenty-seven (27) communities were found to have cases of $B U$ in the three study areas. Statistical analysis was applied to the epidemiological data to identify the relationship between LSTs, elevations and BU disease spread. Results showed that, landscape factors, such as rural and low-lying elevations of between $85 \mathrm{~m}$ and $202 \mathrm{~m}$ above Mean Sea Level as well as LST ranges of $20.8^{\circ} \mathrm{C}$ to $34.2^{\circ} \mathrm{C}$, strongly correlated with BU disease. This research offers an opportunity to explore the effects of elevation and LST conditions on the spread of BU disease caused by MU. Results will contribute to public health and environmental management in the study areas.
\end{abstract}

Keywords: BU, Elevation, LST, $M U$, AWD, UDWD, TNM, Ghana

\section{Introduction}

Buruli Ulcer (BU), an emerging bacterial disease caused by Mycobacterium Ulcerans (MU), is one of 13 classified neglected tropical diseases [1]. It mostly affects poor rural populations in tropical and sub-tropical countries, mostly in West Africa [2]. The disease has been reported in at least thirty-three (33) countries worldwide and is the third most common mycobacterial disease after tuberculosis and leprosy [3]. Landscape determinants such as Land Surface Temperatures (LSTs) and elevations may play important roles in Mycobacterium spread. There are suggestions that low elevations correlate to villages with higher prevalence rate [2]. [4], also suggested that altitude (elevation) could affect BU disease prevalence. Wetlands and ponds in lowlying (low elevation) areas provide ideal environment for $M U$ development. LSTs also reflect surface interactions and energy fluxes between the ground and the atmosphere [5]. Thermal Infrared (TIR) remote sensing data have been shown to provide valuable information on LSTs [6]; [7]; [8]; [9]. These TIR sensors are also utilised to obtain LSTs and emissivity data of different surfaces with varied spatial resolutions and accuracy. Emissivity is the ratio of the radiant energy emitted from a real world body to that emitted by a black body at the same temperature [10]. With satellite technology, remote sensing-based LST is becoming available globally [11]. Remote sensing LST products provide an estimate of the kinetic temperature of the earth's surface temperature [11]; [12]. Remote sensing and Geographic Information System (GIS) technologies have been widely applied in public health study [13]; [14]; [15]; [16]; [9]; [17]; [18]. Though researchers have suggested a link between local climate (temperature) and the occurrence of some diseases and other threats to human health [19]; [20]; [21], studies have not been conducted to simultaneously consider LSTs and elevations in both endemic and non-endemic districts. This study will use in-situ ground truth temperatures and remotely sensed imagery to examine the spatial distribution of LSTs in relation to elevation and $\mathrm{BU}$ disease prevalence.

This study will use the thermal infrared band of the Landsat TM/ETM+/OLI-TIR data, ASTER DEM and field observations to determine the relationship between LST, elevation and BU disease prevalence. The integration of Remote sensing and GIS in this research may help with the analysis as to how elevations and LST conditions impact on $\mathrm{BU}$ disease.

\subsection{LSTs and MU Environments}

LST is an essential climate factor, linked to surface energy balance and the thermal state of the atmosphere [22]. According to [23], the $M U$ grows optimally at temperatures between $29-33{ }^{\circ} \mathrm{C}$ but cannot grow at temperatures above $35^{\circ} \mathrm{C}$ [24]. [23], also stated that $M U$ grows very well under micro-aerophilic conditions at 25 ${ }^{\circ} \mathrm{C}$ and $28{ }^{\circ} \mathrm{C}$ than at higher temperatures [25]. Studies have however not been done to determine the spatial distributions of LSTs of endemic and non-endemic districts of $M U$.

LST is inferred from the thermal emission of the earth surface and is generally some average effective temperature of various canopy and soil surfaces [26]. LST is a key parameter in land surface processes [27]; [28], which can induce local convection in air temperature and precipitation [27] and in turn influence the survival of $M U$ in the environment. 


\section{International Journal of Science and Research (IJSR) ISSN (Online): 2319-7064}

Index Copernicus Value (2015): 78.96 | Impact Factor (2015): 6.391

\section{Elevations and MU environments}

Elevation supports different land covers and thus provides habitats suitable for some bacteria. Variations in elevations will contribute to variations in $M U$ environments. Even though elevation may not change with time, it influences temperature patterns, producing localised temperature conditions that affect soil moisture content. Elevation is also considered to influence $M U$ environments because it relates to precipitation. Generally, as elevation increases, precipitation also increases [29]. [2], suggested that higher prevalence rates were located in low elevation areas. High prevalence of BU disease was associated with farming activities that occurred primarily at low elevations [2]. [30] also stated that persons living in lower elevations appear to have a higher risk of BU. One good reason for the relationship between elevation and $\mathrm{BU}$ prevalence is that since lowlands tend to be wetter than higher grounds, they provide good environmental conditions for the spread of MU [30]. Farmers are also more likely to patronise these wetter lowlands to plant and harvest their crops, thus making them vulnerable to the bacterium.

\section{Materials and Methods Used}

\subsection{Study areas}

The study areas include: Amansie West District (AWD), Upper Denkyira West District (UDWD) and Tarkwa Nsuaem Municipality (TNM). These study areas were selected due to their similarities in socio-economic activities (e.g. illegal "galamsey" mining and farming activities) and BU prevalence. AWD lies between latitudes $6^{\circ} 07^{\prime} \mathrm{N}$ and $6^{\circ} 35^{\prime} \mathrm{N}$ and longitudes $1^{\circ} 42^{\prime} \mathrm{W}$ and $2^{\circ} 08^{\prime} \mathrm{W}$ (Figure 1). The district is bounded by UDWD, Amansie Central district, Bibiani-Anwiaso-Bekwai district, Atwima Mponua district, Atwima Nwabiagya district, Atwima Kwanwoma district and Bekwai Municipal. The district is a tropical rain forest area of about $1320 \mathrm{~km}^{2}$ with an estimated population of 134,331 [31]. It is approximately $60 \mathrm{~km}$ southwest of Kumasi, the regional capital of Ashanti. AWD has the highest BU prevalence rate of 150.8 per 100,000 in the country [32]; [33], and the second highest reported active cases across the country [32]. The main occupation of the people is subsistence farming and small scale "galamsey" mining. The AWD is drained by the Offn and Oda rivers and their tributaries (Figure 1).

UDWD is the second study area and lies between latitudes $5^{\circ} 54^{\prime} \mathrm{N}$ and $6^{\circ} 18^{\prime} \mathrm{N}$ and longitudes $1^{\circ} 49^{\prime} \mathrm{W}$ and $2^{\circ} 12^{\prime}$ $\mathrm{W}$ of the Greenwich Meridian (Figure 2). The district is bounded to the south-east by Upper Denkyira East district, Amansie Central district and Obuasi Municipal. Bounded to the south-west are Wassa Amenfi East and Amansie West districts. The district is also bounded to the northwest by Bibiani-Anwiaso-Bekwai and Wassa Amenfi West districts. UDWD covers an area of about $1700 \mathrm{~km}^{2}$ with an estimated population of about 132,864 [31]. While the Central Region has the highest overall prevalence rate of active cases (Amofah et al., 2002), UDWD is among the most endemic districts in the Region and has the third highest prevalence rate of 114.7 per 100,000 nationwide together with Upper Denkyira East District after Asante Akim North district (prevalence rate of 131.5 per 100,000) and Amansie West district (prevalence rate of 150.8 per 100,000) (Amofah et al., 2002).

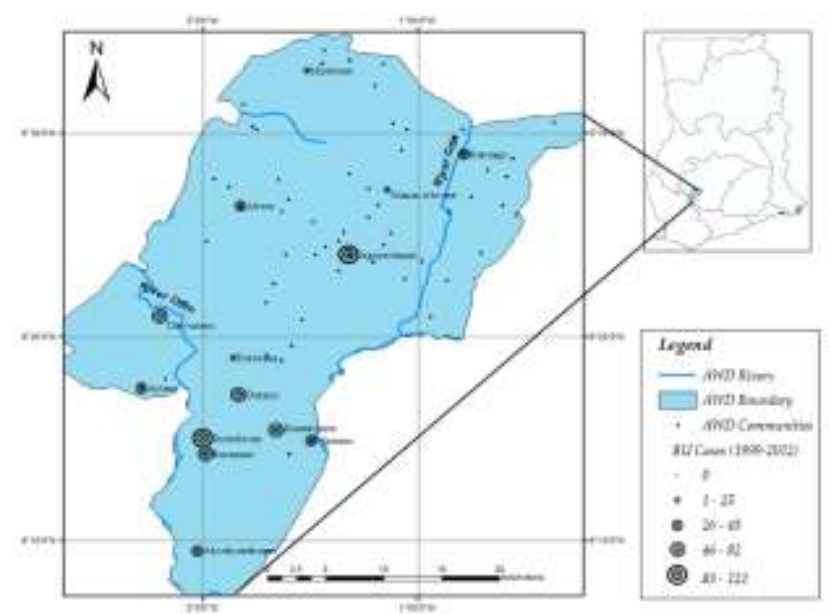

Figure 1: Map of Amansie West District (AWD)

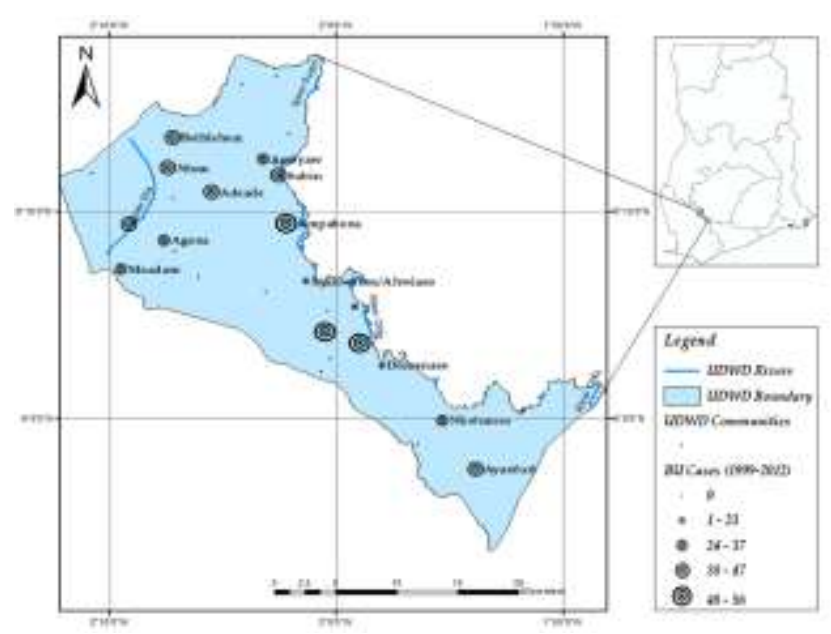

Figure 2: Map of Upper Denkyira West District (UDWD)

Subsistence farming and small scale "galamsey" mining are the main occupation of the people in the district. UDWD is drained by Offin, Dia and Subin rivers as well as their tributaries (Figure 2). The third study area, TNM occupies the mid-southern part of the Western Region of Ghana with Tarkwa as its administrative capital. The TNM is geographically located between latitudes $4^{\circ} 53^{\prime} \mathrm{N}$ and $5^{\circ} 23^{\prime} \mathrm{N}$ and longitudes $1^{\circ} 47^{\prime} \mathrm{W}$ and $2^{\circ} 14^{\prime} \mathrm{W}$ (Figure 3 ). TNM is bounded to the North by Prestea-Huni Valley district, to the South by Ahanta West district, to the West by Nzema East Municipal and to the East by Mpohor Wassa East. According to the 2010 Population and Housing Census [31], the Municipality has a total land area of $1208.7 \mathrm{~km}^{2}$ with a population of approximately 90,477 . Subsistence farming is the major occupation of the people although galamsey mining is also practiced. Largescale mining is the main industrial activity in the TNM [34]. There is only one community (Kedadwen), with reported cases of BU disease in the Municipality. The Municipality is drained by Bonsa and Ankobra rivers as well as their tributaries (Figure 3). 


\section{International Journal of Science and Research (IJSR) ISSN (Online): 2319-7064}

Index Copernicus Value (2015): 78.96 | Impact Factor (2015): 6.391

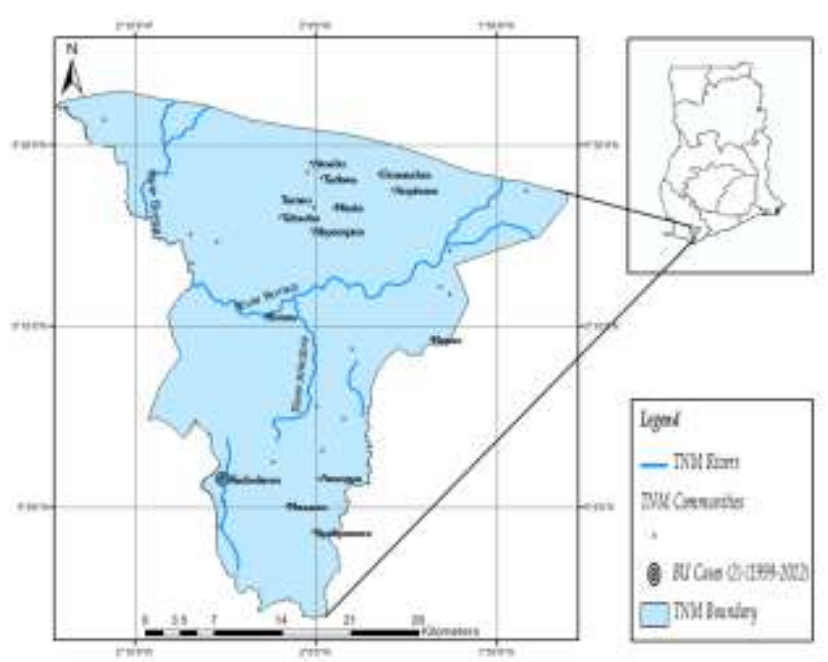

Figure 3: Map of Tarkwa Nsuaem Municipality (TNM)

\subsection{Geo-referencing and Co-registration}

The satellite images were geo-referenced and orthorectified to the Universal Transverse Mercator projection zone 30 North (UTM $30 \mathrm{~N}$ ). The images and the topographic maps were co-registered using 35 ground control points, primarily road intersections, and permanent topographic features across the images in order to have a common projection and datum (Jensen, 2000; Dai and Khorram, 1998). The ASTER DEMs were also reprojected to the UTM Zone $30 \mathrm{~N}$ to align properly with the rest of the data. A first order polynomial model was used for the orthorectification with nearest neighbour resampling. The root mean square (RMS) errors were less than 0.25 pixels $(7.5 \mathrm{~m})$ for each of the images.

\subsection{Radiometric Calibration}

Calibrated DNs of band 3, 4 and 6 for TM and ETM+ as well as band 4, 5 and 10 for OLI-TIRS images were converted to At-sensor spectral radiance $\left(\mathrm{L}_{\lambda}\right)$ using Equation 1 (Chander and Markham, 2003; Sobrino et al., 2004). The values for Lmax/Lmin and QCALmax/QCALmin for Landsat TM/ETM+/ OLI-TIRS used in Equation (1) are shown in Table 1. To minimise scene variability and correct for differences in the EarthSun distance of different Landsat acquisition dates, $\mathrm{L}_{\boldsymbol{\lambda}}$ were subsequently converted to Top-Of-Atmosphere reflectance $(p \lambda)$ using Equation 2.

$L_{\mathrm{A}}=\left\{\frac{\mathrm{Lmax}-\mathrm{Lmin}}{\mathrm{QCALmax}-\mathrm{QCALmin}}\right\} * \mathrm{QCAL}+\mathrm{Lmin}$

$$
\text { Equation (1) where: }
$$

- $\mathrm{L}_{\lambda}$ is the spectral radiance at the sensor's aperture.

- QCAL is the quantized calibrated pixel value in DN

- $\mathrm{L}_{\min }$ is the spectral radiance that is scaled to QCALMIN in $\mathrm{mWcm}^{-2} \mathrm{sr}^{-1}$

- $\mathrm{L}_{\max }$ is the spectral radiance that is scaled to QCALMAX in $\mathrm{mWcm}^{-2} \mathrm{sr}^{-1}$

- $\mathrm{QCAL}_{\text {min }}$ is the minimum quantized calibrated pixel value (corresponding to $\mathrm{LMIN}_{\lambda}$ ) in $\mathrm{DN}$

- $\mathrm{QCAL}_{\max }$ is the maximum quantized calibrated pixel value (corresponding to $\mathrm{LMAX}_{\lambda}$ ) in $\mathrm{DN}$
Table 1: Lmax/Lmin and QCALmax/QCALmin of Landsat TM/ETM+/OLI-TIRS Data

\begin{tabular}{|c|c|c|c|c|c|}
\hline $\begin{array}{c}\text { Band } \\
\text { No }\end{array}$ & Satellite/Sensor & Lmax & Lmin & QCALmax & QCALmin \\
\hline 6 & Landsat 4/TM & 15.30 & 1.24 & 255.00 & 1.00 \\
\hline 6.1 & $\begin{array}{c}\text { Landsat } \\
\text { 7/ETM+ }\end{array}$ & 17.04 & 0.00 & 255.00 & 1.00 \\
\hline 6.2 & $\begin{array}{c}\text { Landsat } \\
\text { 7/ETM+ }\end{array}$ & 12.65 & 3.20 & 255.00 & 1.00 \\
\hline 10 & $\begin{array}{c}\text { Landsat } \\
\text { 8/OLI/TIRS }\end{array}$ & 22.00 & 0.10 & 65535.00 & 1.00 \\
\hline
\end{tabular}

$p \lambda=\left(\pi d^{2} L_{\lambda}\right) /\left(\operatorname{ESUN}_{\lambda} \cos \theta_{s}\right) \ldots$. Equation (2)

where:

- $p \lambda$ is the reflectance as a function of bandwidth (Planetary reflectance)

- $\mathrm{d}$ is the Earth-sun distance correction

- $\mathrm{L}_{\lambda}$ is the radiance as a function of bandwidth

- $\mathrm{ESUN}_{\lambda}$ is the mean solar exoatmospheric spectral irradiance

- $\theta_{\mathrm{g}}$ is the solar zenith angle in degrees

\subsection{Determination of the Land Surface Temperatures}

LSTs are dependent on Normalized Difference Vegetation Indices (NDVIs). NDVIs were used to determine vegetation proportion $\left(\boldsymbol{P}_{v}\right)$, which was also used to compute the Land surface emissivity $(\varepsilon)$. The NDVIs were computed from the Landsat data using Equation 3.

$N D V I=\frac{\text { NIR-Red }}{\text { NIR-Red }} \ldots \ldots \ldots \ldots . . .$. Equation (3) where: NIR is the Near-infrared and Red is the visible red spectrum of light. The At-sensor spectral radiance of band 6 and 10 were converted to At-sensor brightness temperature $\left(T_{B}\right)$ by applying Plank's inverse function. Equation (4) [37] was used to convert radiance to brightness temperature.

$\mathrm{T}_{\mathrm{B}}=\frac{\mathrm{K}_{2}}{\operatorname{In}\left(\frac{\mathrm{K}_{1}}{\mathrm{~L}_{\mathrm{\lambda}}}+1\right)} \ldots \ldots . .$. Equation (4)

where, $T_{B}$ is the brightness temperature in degree Kelvin, $\mathrm{L}_{\lambda}$ the TOA radiance at the sensor's aperture, $\mathrm{K}_{1}$ is the prelaunch calibration constant 1 in $\mathrm{W} /\left(\mathrm{m}^{2}\right.$ sr $\left.\mu \mathrm{m}\right)$ and $\mathrm{K}_{2}$ is the pre-launch calibration constant 2 in Kelvin.+ The calibration constants $\mathrm{K}_{1}$ and $\mathrm{K}_{2}$ obtained from Landsat data user's manual are given in Table 2 .

Table 2: Calibration Constants for Thermal Band

\begin{tabular}{|c|c|c|c|c|}
\hline & L4 TM & L5 TM & L7 ETM+ & $\begin{array}{c}\text { L8 OLI/TIRS- } \\
10\end{array}$ \\
\hline $\mathrm{K}_{1}$ & 671.62 & 607.76 & 666.09 & 774.89 \\
\hline $\mathrm{K}_{2}$ & 1284.30 & 1260.56 & 1282.71 & 1321.08 \\
\hline
\end{tabular}

The vegetation proportion $\left(\boldsymbol{P}_{v}\right)$ which is required to calculate the emissivity is determined from Equation (5) [38] :

$P_{V}=\left[\frac{N D V I-N D V I_{\min }}{N D V I_{\text {max }}-N D V I_{\min }}\right]^{2} \ldots . .$. Equation (5) Land surface emissivity ( $\varepsilon$ ) was then determined from Equation (6) 


\section{International Journal of Science and Research (IJSR) ISSN (Online): 2319-7064}

Index Copernicus Value (2015): 78.96 | Impact Factor (2015): 6.391

[38]. $\varepsilon_{T M 6}=0.004 P_{V}+0.986 \quad \ldots \ldots .$. Equation (6) The LST in degree Kelvin was estimated by Equation (7) [39]; [40]. LST $=\frac{\mathrm{T}_{\mathrm{B}}}{\ln \mathrm{In}\left(\mathrm{T}_{\mathrm{B}} / \mathrm{p}+\lambda+1\right.} \ldots \ldots \ldots \ldots$. Equation (7) where $\lambda$ is the wavelength of emitted radiance which is equal to $11.5 \mu \mathrm{m} \mathrm{[39];} \mathrm{[40],} \rho=$ h.c/ $\sigma\left(1.438 \times 10^{-2} \mathrm{~m} \mathrm{~K}\right), \sigma=$ Boltzmann constant $\left(1.38 \times 10^{-23} \mathrm{~J} / \mathrm{K}\right), \mathrm{h}=$ Planck's constant $\left(6.626 \times 10^{-34} \mathrm{~J} \mathrm{~s}\right), \mathrm{c}=$ velocity of light $(2.998 \times$ $10^{8} \mathrm{~m} / \mathrm{sec}$ ) and $\varepsilon=$ the land surface emissivity. The final LST map was converted from degree Kelvin to degree Celsius using Equation (8):

\subsection{Quality Assessment and Validation of Land Surface Temperature}

GIS point coverage of 10 in-situ meteorological stations were generated and projected onto the LST maps of the meteorological stations. The LSTs from the meteorological stations were then retrieved from the Landsat thermal bands. The surface emissivity and solar zenith angles which are important factors affecting LSTs [41]; [42], were also retrieved from the multispectral Landsat data and solar elevations from the metadata respectively. Ground truth temperatures for each of the meteorological stations concurrent with Landsat overpass and acquisition dates were also retrieved from the Ghana Meteorological Agency.

$$
\begin{aligned}
& \text { LST }(\text { degree Celsius })=\text { LST }(\text { degree Kelvin })- \\
& 273 \ldots \ldots \ldots \ldots \ldots \ldots \ldots \ldots \ldots \text { Equation }(8)
\end{aligned}
$$

\subsection{Processing Digital Elevation Models}

The DEM was clipped to the study areas and corrected by "filling sink" in order to minimise sinks due to errors. Color-relief was then generated to assign symbols to different elevations. BU communities were overlaid on the processed DEM. The average elevations of BU communities and their surrounding elevations were extracted and compared with BU cases.

\section{Results and Discussions}

The results of LSTs from Landsat TM/ETM+/OLI-TIRS satellite images indicate that, BU disease endemic communities in the study areas have average temperatures of between $20.8{ }^{\circ} \mathrm{C}$ and $34.2{ }^{\circ} \mathrm{C}$ (Figure 4 to 6). A simple regression analysis was performed to compare ground truth temperatures and LSTs derived from the thermal Landsat data.

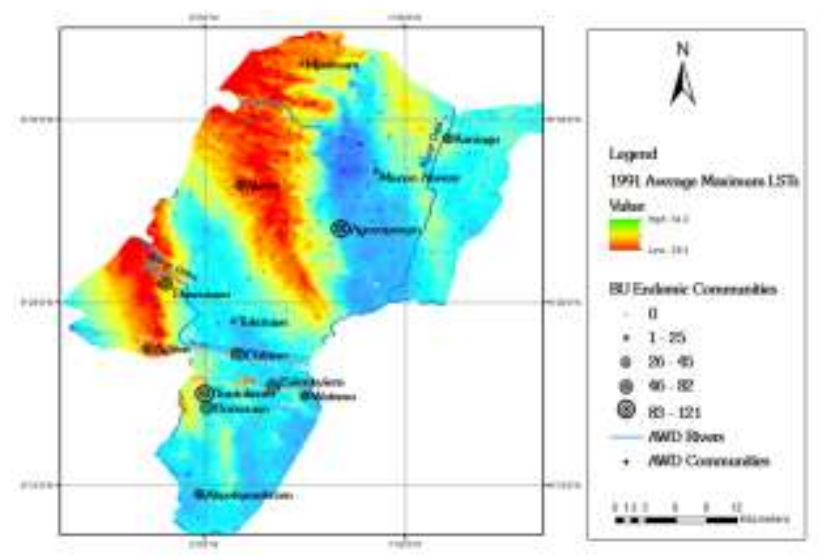

Figure 4: Average Maximum LST for AWD

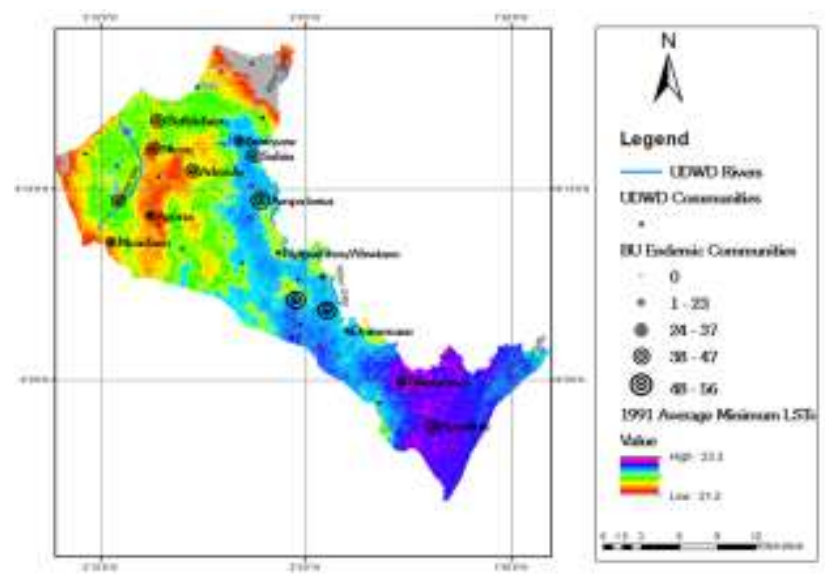

Figure 5: Average Minimum LST for UDWD

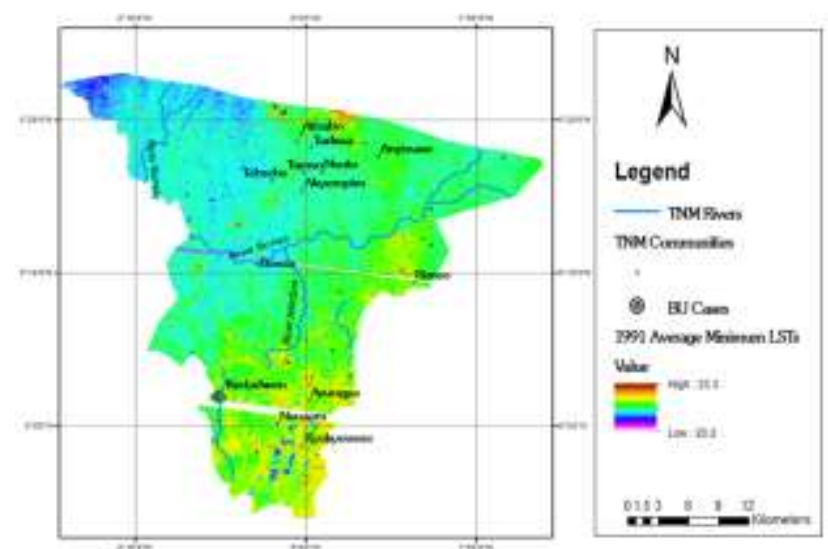

Figure 6: Average Minimum LST for TNM

The temperatures for all the three study areas range between $20.8{ }^{\circ} \mathrm{C}$ and $34.2{ }^{\circ} \mathrm{C}$. The bacterium grows optimally under micro-aerophilic temperatures (i.e., between $25{ }^{\circ} \mathrm{C}$ and $28{ }^{\circ} \mathrm{C}$ ) [23], than at higher temperatures [43]; [44]. According to Anon. (2013) the optimal growth of MU is given as $30{ }^{\circ} \mathrm{C}-32{ }^{\circ} \mathrm{C}$. The deterministic coefficient $\left(\mathrm{R}^{2}\right)$ obtained for the minimum and maximum temperatures were 0.875 and 0.712 , which indicate that the ground truth temperatures at the meteorological stations correlated well with the satellite derived LSTs.

The digital elevation models as well as $2 \mathrm{D}$ contour profiles of BU endemic communities and surrounding landscapes were also generated. 


\section{International Journal of Science and Research (IJSR) ISSN (Online): 2319-7064}

Index Copernicus Value (2015): 78.96 | Impact Factor (2015): 6.391

From the digital elevation models and the 2D contour profiles, the elevation of BU-prone settlements range between $134 \mathrm{~m}-216 \mathrm{~m}$ of which $64 \%$ fall below $160 \mathrm{~m}$ in the AWD. In the UDWD also, elevation of BU-prone settlements range between $90 \mathrm{~m}-149 \mathrm{~m}$, of which $77 \%$ fall below $135 \mathrm{~m}$. TNM has elevation ranging from $60 \mathrm{~m}$ $150 \mathrm{~m}$ of which $85 \%$ fall below $100 \mathrm{~m}$.

\section{Conclusions}

The average temperatures for $\mathrm{BU}$ endemic communities in the study areas range between $20.8{ }^{\circ} \mathrm{C}$ to $34.2{ }^{\circ} \mathrm{C}$. The average elevations in $\mathrm{BU}$ endemic communities also range between $85 \mathrm{~m}$ and $202 \mathrm{~m}$ above Mean Sea Level. The BU endemic communities are generally surrounded by landscapes of high elevations. Wetlands and ponds in lowlying areas provide ideal places where perhaps harmful elements emanating from mines are deposited to favour $M U$ development. Relatively low-lying rural communities have the highest BU prevalence in the study areas.

\section{Reference}

[1] Anon, (2008), "World Health Organization Buruli ulcer: progress report, 2004-2008". Weekly Epidemiological Record, 2008; 17: pp. 145-54.

[2] Wagner T., Benbow E. M., Brenden O. T., Qi J. and Johnson R. C., (2008), Buruli ulcer disease prevalence in Benin, West Africa: associations with land use/cover and identification of disease clusters. International Journal of Health Geographics, 7: pp. 25.

[3] Anon., (2012a), "Buruli ulcer, (Mycobacterium ulcerans infection)",

http://www.who.int/mediacentre/factsheets/fs199/en/.

Accessed: December 27, 2017.

[4] Ghislain Emmanuel Sopoh, Roch Christian Johnson, Séverin Yehouénou Anagonou, Yves Thierry Barogui, Ange Dodji Dossou, Jean Gabin Houézo, Delphin Mavingha Phanzu, Brice Hughes Tente, Wayne M. Meyers, and Françoise Portaels, (2011), "Buruli Ulcer Prevalence and Altitude, Benin", Emerging Infectious Diseases; 17(1): pp.153-154.

[5] Wan, Z., and Dozier, J. (1996). A generalized splitwindow algorithm for retrieving land-surface temperature from space. IEEE Transactions on Geoscience and Remote Sensing, 34(2), pp. 892-905.

[6] Quattrochi, D. A., and Ridd, M. K. (1998), Analysis of vegetation within a semi-arid urban environment using high spatial resolution airborne thermal infrared remote sensing data. Atmosphere Environment, 32(1), pp. 19-33.

[7] Owen, T. W., Carlson, T. N., and Gillies, R. R. (1998), An assessment of satellite remotely-sensed land cover parameters in quantitatively describing the climatic effect of urbanization. International Journal of Remote Sensing, 19, pp. 1663-1681.

[8] Hirano, Y., Yasuoka, Y., and Ichinose, T. (2004), Urban climate simulation by incorporating satellite-derived vegetation cover distribution into a mesoscale meteorological model. Theoretical and Applied Climatology, 79, pp. 175-184.

[9] Weng, Q., Lu, D. and Schubring, J. (2004), Estimation of land surface temperature-vegetation abundance relationship for urban heat island studies. Remote Sensing of Environment, 89, pp. 467-483.
[10] Jensen, J. R., (2000), Remote sensing of the environment: An earth resource perspective, PrenticeHall, New Jersey, pp. 181-243, 333-529.

[11] Dickinson, R. E. (1994), "Satellite systems and models for future climate change. Future Climates of the World": A Modelling Perspective, A. Henderson-Sellers, Ed., 16, World Survey of Climatology, Elsevier, 27pp.

[12] Becker, F., and Li, Z. L. (1995), "Towards a local split window method over land surface", International Journal of Remote Sensing, Vol. 3, pp. 17-33.

[13] Anyamba, A., Chretien, J. P., Small, J., Tucker, C. J., and Linthicum, K. J. (2006), Developing global climate anomalies suggest potential disease risks for 2006-2007. International Journal of Health Geographics, Vol. 5, Issue1, pp. 60.

[14] Sannier, C. A. D., Taylor, J. C., and Campbell, K. (1998), Compatibility of FAO-ARTEMIS and NASA Pathfinder AVHRR Land NDVI data archives for the African continent. International Journal of Remote Sensing, 19, pp. 3441-3450.

[15] Hay, S. I., and Lennon, J. J. (1999), Deriving meteorological variables across Africa for the study and control of vector-borne disease: A comparison of remote sensing and spatial interpolation of climate. Tropical Medicine and International Health, 4, pp. 58-71.

[16] Wang, Y., Zhang, X., Liu, H., and Ruthie, H. K. (1999), Landscape characterization of metropolitan Chicago region by Landsat TM. In The Proceeding of ASPRS Annual Conference pp. pp. 238-247.

[17] Herbreteau, V., Salem, G., Souris, M., Hugot, J., and Gonzalez, J. (2007), Thirty years of use and improvement of remote sensing, applied to epidemiology: From early promises to lasting frustration. Health \& Place, 13(2), pp. 400-403.

[18] Zou, L., Miller, S. N., and Schmidtmann, E. T. (2006), Mosquito larval habitat mapping using remote sensing and GIS: Implications of coalbed methane development and West Nile virus, Journal of Medical Entomology, 43(5), pp. 1034-1041.

[19] Anon, [http://www.climate.org/topics/health.html] accessed on 27/01/2017.

[20] Gallo, K. P. and Owen, T. W. (1999), Satellite-based adjustments for the urban heat island temperature bias. Journal of Applied Meteorology, 38, pp. 806-813.

[21] Roth, M., Oke, T. R. and Emery, W.J. (1989), Satellitederived urban heat islands from three coastal cities and the utilization of such data in urban climatology. International Journal of Remote Sensing, 10: pp. 16991720.

[22] Jin, M., and Liang, S. (2006), "An Improved Land Surface Emissivity Parameter for Land Surface Models Using Global Remote Sensing Observations", American Meteorological Society, pp. 2867-2881.

[23] Jenkins, P. A., Pattyn, S. R. and Portaels, F. (1982), Diagnostic bacteriology. In: Rattledge, C. and Stanford, J. (eds), The biology of the mycobacteria, Academic Press Ltd., London, Vol. 1, pp. 441-470.

[24] Mve-Obiang, A., Lee, R. E., Umstot, E. S., Trott, K. A., Grammer, T. C., Parker, J. M. , Ranger, B. S., Grainger, R. , Mahrous, E. A. and Small, P. L., (2005), A newly discovered mycobacterial pathogen isolated from laboratory colonies of Xenopus species with lethal infections produces a novel form of mycolactone, the Mycobacterium ulcerans macrolide toxin. Infection and Immunity, Vol. 73, pp. 3307-3312.

\section{Volume 6 Issue 12, December 2017}




\section{International Journal of Science and Research (IJSR) \\ ISSN (Online): 2319-7064}

Index Copernicus Value (2015): 78.96 | Impact Factor (2015): 6.391

[25] Tsukamura, M. (1983), "Numerical classification of 280 strains of slowly growing mycobacteria", Microbiology Immunology, Vol. 27, pp. 315-334.

[26] Betts, A. K., Ball, J. H., Beljaars, A. C. M., Miller, M. J. and Viterbo, P. A. (1996), "The land surface-atmosphere interaction: A review based on observational and global modeling perspectives", Journal of Geophysical Resources, Vol. 101, pp. 7209- 7225.

[27] Aires, F., C. Prigent, W. B. Rossow, and Rothstein M., (2001), A new neural network approach including firstguess for retrieval of atmospheric water vapor, cloud liquid water path, surface temperature and emissivities over land from satellite microwave observations, Journal of Geophysical Research, Vol. 106, pp. 14887-14907.

[28] Sun, D. and Pinker, R. T. (2003), "Estimation of land surface temperature from a Geostationary Operational Environmental Satellite (GOES-8)", Journal of Geophysical Research, Vol. 108, pp. 4326-4241.

[29] Şen, Z. (2009), "Discussion of "Validity of Regional Rainfall Spatial Distribution Methods in Mountainous Areas" by Bahram Saghafian and Sima Rahimi Bondarabadi”, Journal of Hydrologic Engineering, Vol. 14, No. 7, pp. 770-771.

[30] Duker, A. A., Carranza, E. J. M., Hale, M. (2004), "Spatial dependency of Buruli ulcer prevalence on arsenic-enriched domains in the Amansie West District, Ghana: implications for arsenic mediation in Mycobacterium ulcerans infection", International Journal of Health Geographics, Vol. 3, 19pp.

[31] Anon., (2012b), "2010 Population and Housing Census, Summary Report of Final Results", Ghana Statistical Services, Sakoa Press Limited, 11 pp.

[32] Amofah, G. K., Bonsu, F., Tetteh, C., Okrah, J., Asamoah, K. and Asiedu, K., (2002), Buruli ulcer in Ghana: results of a national case search, Emerging Infectious Diseases, Vol. 8, pp. 167-70.

[33] Amofah, G. K. (1995), "Control and management of Buruli ulcer disease", Ghana Medical Journal, Vol. 29, pp. 589-602.

[34] Avotri, T. S. M., Amegbey, N. A., Sandow, M. A., and Forson, S. A. K. (2002). The health impact of cyanide spillage at Goldfields Ghana Ltd., Tarkwa. Report May 2002.

[35] Dai, X.L. and Khorram, S., (1998), "The effects of image misregistration on the accuracy of remotely sensed change detection", IEEE Transaction on Geoscience and Remote Sensing, Vol. 36, pp. 1566-1577.

[36] Chander, G., and Markham, B. (2003). Revised Landsat5 TM radiometric calibration procedures and postcalibration dynamic ranges. IEEE Transactions on Geoscience and Remote Sensing, 41(11), pp. 2674-2677.

[37] Sobrino, J. A., Jimenez-Munoz, J. C. and Paolini, L. (2004), Land surface temperature retrieval from LANDSAT TM 5, Remote Sensing of Environment, vol. 90, pp. 434-440.

[38] Carlson, T. N. and Ripley, D. A., (1997), "On the relation between NDVI, fractional vegetation cover, and leaf area index", Remote Sensing of Environment, Vol. 62, pp. 241-252.

[39] Markham, B. L. and Barker, J. L. (1985), "Spectral characterization of the LANDSAT Thematic Mapper sensors", International Journal of Remote Sensing, Vol. 6, pp. 697- 716.

[40] Artis, D. A., and Carnahan, W. H., (1982), "Survey of emissivity variability in thermography of urban areas", Remote Sensing of Environment, Vol. 12, pp. 313-329.
[41] Snyder, W. C., Z. Wan, and Y. Z. Feng (1998), Classification-based emissivity for land surface temperature measurement from space, International Journal of Remote Sensing, Vol. 19, No. 14, pp. 27532774.

[42] Dubayah R. and P. M. Rich, (1995), Topographic solar radiation models for GIS, International Journal of Geographic Information System, Vol. 9, No. 4, pp. 401419.

\section{Author Profiles}

Saviour Mantey is a Senior Lecturer at UMaT, Ghana. He was awarded BSc (Hons) in Geodetic Engineering at KNUST, Ghana. He obtained MPhil degree in GIS and Remote Sensing from Cambridge University, UK. He holds a $\mathrm{PhD}$ in Geomatic Enginering from UMaT, Ghana. He is a Fellow of the Cambridge Commonwealth Society. His research interest includes Web-GIS Applications, Remote Sensing and GIS in Environmental Analysis and Drones/UAV applications. He is a Member of IEEE-GRSS, AARSE and GhIS.

Naa Dedei Tagoe is a Lecturer at UMaT, Ghana. She was awarded BSc (Hons) degree in Geodetic Engineering at KNUST, Ghana. She obtained her MSc degree in Photogrammetry and Geoinformatics from Stuttgart University of Applied Sciences, Germany. She holds a $\mathrm{PhD}$ in Photogrammetry from University of Cape Town, South Africa. Her research interests include Close Range Photogrammetry, 3D Modelling of Cultural Heritage Sites, Remote Sensing, Web-GIS Applications and Drones/UAVs. She is a Mandela Washington Fellow and a member of Graduate women International and the Ghana Institution of Surveyors.

\section{Volume 6 Issue 12, December 2017}

